\title{
PENALARAN USHUL FIQH IBNU HAZM (Analisis Penolakan Illat dan Qiyas Sebagai Dalil Hukum Islam)
}

\author{
Nur Khoirin YD \\ Universitas Islam Negeri Walisongo Semarang \\ nur_khoirin@walisongo.ac.id
}

\begin{abstract}
Ibn Hazm al Qurthubi is among the opponents of the use of illat and qiyas arguing that nash of al-Qur'an and Hadith can be applied to any problems simply by understanding ma'na and dhahir of texts. Reasoning of musbit al-Qiyas (the proponents of Qiyas) that syari'a does not provide answer to all problems is a false logic according to Ibn Hazm since this argument contradicts to al-Qur'an's statement. Whoever uses qiyas as a legal reasoning is similar to believing that Qur'an is failed to provide guidance. In the process of legal reasoning, Ibn Hazm would refer to al-Qur'an, Hadith and Ijma'. Should those three sources do not provide the answer, he used dalil by understading the hidden meaning of the texts.
\end{abstract}

Keyword: Ibn Hazm, Illat, Qiyas, Dalil, Islamic law.

\section{A. MUKADDIMAH}

Qiyas adalah salah satu dari empat sumber hukum Islam yang disepakati oleh para ulama (muttafaq 'alaih) setelah al-Qur' an, AsSunnah dan al-Ijma'. Selebihnya adalah dalil-dalil yang masih diperselisihkan penggunaannya (mukhtalaf 'alaih), seperti istihsan, maslahah mursalah, istishab, urf, madzhab shahabi, syar'u man qablana dan sebagainya. Hampir tidak ada kitab Ushul Fiqh yang melewatkan pembahasan Qiyas dalam bab mengenai dalil-dalil Syara'. Qiyas telah identik dengan ushul fiqih, karena pembahsan ushul fiqh tidak lengkap tanpa qiyas. Ini menunjukkan qiyas mempunyai kedudukan yang penting dalam pembahasan sumbersumber hukum Islam.

Qiyas sebagai urutan ke empat dari sumber hukum setelah alQur'an, As-Sunnah dan al-Ijma', ini artinya menunjukkan hirarki dalil-dalil Syara' dari yang paling kuat keurutan yang lebih 
lemah.Dalam menemukan hukum terhadap peristiwa baru (waqi'ah), maka pertama kali harus dicari dalilnya di dalam alQur'an. Jika ditemukan hukumnya didalam Al Qur'an, maka wajib ditetapkan hukumnya berdasarkan Al-Qur'an. Jika tidak ditemukan, maka harus dicari di dalam as-Sunnah. Sekiranya asSunnah juga tidak ditemukan, maka harus dicari apakah pernah disepakati hukumnya oleh para sahabat atau ulama, kalau ada harus ditetapkan berdasarkan ijma' itu. Jika ternyata juga tidak ditemukan ijma', maka baru dipergunakan qiyas, dan begitu seterusnya menurut urutan prioritas dalil yang disepakati.

Meskipun jumhur ushuliyyin menyepakati qiyas sebagai dalil hukum yang kuat, tetapi ada ulama yang menentang penggunaan qiyas sebagai dalil hukum. Dia adalah Ibn Hazm, fuqaha yang terkenal memahami dalil cukup dengan zahir nash dan menolak keras penalaran dengan metode 'illat dan qiyas. Menurutnya, nash al-qur'an dan hadits telah sempurna dan komplit maka mencari 'illat atau menganalogikan merupakan pekerjaan yang tidak diperlukan (Ibnu Hazm al-Dzahiri, Juz 8:515). Dalam memahami dan menggunakan dalil ia memilih corak tersendiri, yang meskipun Nampak tekstual tetapi juga menggunakan logika yang sulit dibantah. Argumen-argumen yang dibangunnya sering diistilahkan dengan al Burhan.

Penalaran Ibnu Hazm yang nyleneh ini menarik untuk didiskusikan sebagai salah satu ikhtiar untuk penyegaran metodologi pemahaman nash-nash hukum Islam yang praktis dan efektif, tetapi tetap sejalan dengan maksud-maksud Syari'. Pembahasan ini difokuskan kepada penalaran ushul fiqh Ibnu Hazm tentang penolakan 'illat dan qiyas, cara pemahaman dalil dan penggunaannya serta makna burhan yang sering dipakai Ibn Hazm.

\section{B. Biografi Ringkas Ibn Hazm}

Nama lengkapnya adalah Ali ibn said Ibn Hazm Ibn Ghalib Ibn Shaleh Ibn Khalaf Ibn Ma'dan Ibn Sufyan Ibn Yazid. Kalangan penulis kontemporer memakai nama singkatnya yang populer $I b n$ Hazm, dan terkadang di hubungkan dengan panggilan al-Qurthubi atau al-Andalusi dengan menisbatkannya kepada tempat kelahirannya, Cordova dan Andalus. Ibnu Hazm juga sering dikaitkan dengan sebutan al-Dhahiri, sehubungan dengan aliran fiqih dan pola pikir dhahiri yang dianutnya. Sedangkan Ibn Hazm 
sendiri memanggil dirinya dengan Abu Muhammad sebagaimana di temukan dalam karya - karya tulisnya.

Ibn Hazm lahir di kota Cordova Andalusia pada waktu subuh hari terakhir dari bulan Ramadhan 384 H $/ 7$ November 994 M (Gibb dan Krammer,1961:147). Ia termasuk keturunan Arab suku Quraisy. Ayahnya Ahmad Ibn Sa'id, berpendidikan cukup tinggi, sehingga dia diangkat menjadi pejabat di lingkungan kerajaan alManshur dan kemudian menjadi wazir al-Manshur pada tahun $381 \mathrm{H}$ / 991M. dia menjabat wazir sampai di masa pemerintahan alMuzaffar dan meninggal pada tahun $402 \mathrm{H}$.

Sejak usia kanak-kanak Ibn Hazm telah menampakkan kecintaannya yang kuat meminati ilmu dan belajar lebih banyak. Setelah usia remaja ia selalu diajak ayahnya menghadiri majelismajelis ilmiah dan budaya yang sering diadakan oleh al-Manshur yang dihadiri oleh para ahli sya'ir dan ilmuwan. Di samping oleh ayahnya sendiri, Ibn Hazm juga mendapat bimbingan secara intensif dari seorang alim dan wara', Ali al-Husein Ibn Ali al-Fasy.

Ibnu Hazm belajar kepada para ulama kenamaan seperti Abu Muhamad ibn Dakhun, Abdullah al-Azdi, Abi qasim Abdurahman bin Abi Yazid al-Misri, dan masih banyak lagi sederatan ulama yang kadar keilmuannya diakui oleh rakyat Qordoba. Dari didikan para ulama itulah akhirnya ia menjadi seorang pakar dalam bidang agama. Kepakarannya bukan hanya diakui oleh kaum muslimin, namun juga diakui oleh sarjana Barat. Bukan Cuma ilmuan, ia juga menguasai ilmu kenegaraan. Ia pernah menjabat sebagai menteri pada pemerintahan Cordoba.

Walau dikelilingi dengan gemerlap kemewaan, namun tidak menjadikannya lupa akan kedudukan dan kewajiban agama. Ia sangat interest dengan keilmuan Islam. Kondisi sosial, politik, mental dan intelektual yang melatarbelakanginya, justru menjadi faktor pendorong bagi Ibnu Hazm untuk menjalani hidup dalam pengembaraan mencari jati diri. Saat berkelana itulah ia mengenal ilmu dan ulama. Dan dari para ulama inilah ia mendalami intisari agama.

Ibn Hazm diakui sebagai seorang ulama yang memiliki kontribusi luar biasa dalam dunia Islam. Tak kurang dari 400 judul kitab telah ditulisnya. Tetapi kitab-kitabnya banyak yang dibakar dan dimusnahkan oleh penguasa al-Mu'tamid Ibn Ibad, karena dikhawatirkan akan menyaingi madzhab resmi Maliki dan karena kritiknya yang tajam kepada pemerintah.

Yudisia, Vol. 9, No. 1, Jan-Jun 2018 
Melalui karya-karyanya itu, ia diakui sebagai filusuf, teolog, sejarawan, sastrawan, pakar fikih, negarawan, akademisi dan politisi yang handal. Dua karya monumentalnya al Ihkam fi Ushul al Ahkam (Ushul Fikih) dan kitab al Muhalla (Fikih) menjadi rujukan utama fuqaha mu'ashirin (pakar fikih kontemporer) dalam upaya penyelarasan khazanah fikih Islam. Karyanya yang lain, berjudul Tauqul Hamamah (Di Bawah Naungan Cinta) menjadi kitab terlaris sepanjang abad pertengahan. Kitab yang berisi sebuah kompilasi anekdot, observasi, dan puisi tentang cinta ini tidak hanya menarik bagi umat Islam, tetapi juga kaum Nasrani di Eropa.

Di kalangan sarjana Islam, Ibnu Hazm dikenal sebagai ilmuwan yang memiliki keunikan dalam kajian-kajiannya. Ia memiliki metodologi sendiri dalam memahami ajaran Islam yang berbeda dengan fuqaha arba'a (ulama empat madzhab). Ia menolak al qiyas (dalil analog) yang telah disepakati oleh jumhur ulama (mayoritas ulama) sebagai salah satu landasan hukum syari'at. Alasan Ibnu Hazm menolak qiyas karena menurutnya persoalan agama tidak boleh dipecahkan dengan al Qiyas dan ar Ra'yu, sebab perselisihan pendapat dalam Islam harus dikembalikan pada al Qur'an dan as Sunnah. Ibnu Hazm juga beranggapan bahwa madzhab yang berpengaruh saat itu, telah mempolitisir hakikat ajaran Islam. Karenanya, ia membuat sebuah metodologi yang berbeda dengan mazhab yang ada.

Untuk mensosialisasikan metodenya itu, ia sering membuat forum kajian dan menuangkan pandangan-pandangannya dalam sebuah media tulisan. Hanya saja, cara yang dilakukan sangat provokatif sehingga tidak disenangi oleh kaum Muslimin. Misalkan dalam al Muhalla Ibnu Hazm sering menggunakan kata 'orang ini tidak beriman', untuk mengejek orang yang menggunakan ra'yu. Karena sikapnya seperti itu, tak heran jika para ulama pada jamannya mengkritik habis-habisan sikapnya.

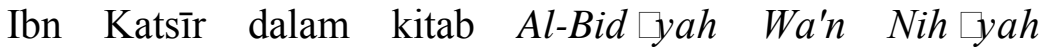
menjelaskan bahwa Ibnu Hazm sangat sering mencela ulama dengan pena dan lisannya. Hal ini yang menyebabkan masyarakat pada zaman tersebut membencinya. Ia juga menilai Ibnu Hazm sebagai orang yang kebingungan dalam hal furū' (fiqh) yang tidak berpegang pada qiyās, baik yang jali (sangat jelas) maupun selainnya.

Ibnu Hazm wafat di kota Manta Lisan (Spanyol) pada 28 Sya'ban 456H bertepatan tanggal 15 Agustus 1064M (Syamsuddin 
Adz Dzahabi, 1993:184). Wafatnya cukup membuat masyarakat kala itu merasa kehilangan dan terharu. Khalifah Mansur alMuwahidi, khalifah ketiga dari Bani Muwahid termenung menatap kepergian Ibn Hazm, seraya berucap: "Setiap manusia adalah keluarga Ibn Hazm". Mungkin ungkapan ini terilhami dengan riwayat hidupnya yang dihabiskan pengembaraan sehingga banyak keluarga dimana-mana.

\section{Penolakan terhadap 'Illat Hukum}

'Illat secara sederhana dapat diartikan suatu sifat atau keadaan yang dijadikan alasan ditetapkannya suatu hukum. Dari pengertian ini lahirlah kaidah illat yang sangat popular "al hukumu yaduru ma'a 'illatihi wujudan wa 'adaman". Ulama ushul berbeda-beda dalam merumuskan definisi illat, tetapi dalam aplikasinya tidak jauh beda. Ulama mutaakhirin (komtemporer) mendefinisikan illat dengan memperhatikan persyaratan atau unsur yang harus ada dalam illat, harus jelas, terukur, dan munasabah dengan hukum. Salah satunya dikemukakan oleh Musthofa As Syalaby sebagai berikut :

"Illat adalah suatu sifat (keadaan/hal/faktor) yang jelas, dapat diukur dan relevan dengan hukum, menentukan ada atau tidaknya suatu hukum, bertujuan untuk mewujudkan kemaslahatan manusia, baik berupa kemanfaatan maupun menghindarkan diri dari kerusakan" (M. Mustafa Syalaby, 1981:13 dan Abdul Wahab al-Khalaf, 1978:63).

Contoh-contoh penerapan 'Illat yang selalu dikemukakan oleh ulama dalam kitab-kitab ushul fiqh, misalnya dalam ayat:

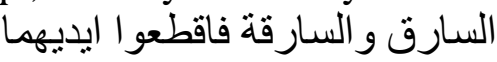

Dalam ayat ini mencuri dijadikan sebagai illat adanya hukum potong tangan.

Sabda Nabi: لايرث القاتل, dalam hadits ini membunuh ahli waris menjadi illat tidak dapat warisan dari harta yang dibunuh. Firman Allah:

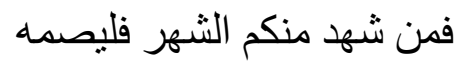

Melihat terbitnya bulan menjadi Illat wajib puasa. Demikian juga dalam ayat :

Yudisia, Vol. 9, No. 1, Jan-Jun 2018 


$$
\text { اقم الصلاة لدلوك الثمس الى غسق الليل }
$$

Tergelincirnya matahari menjadi illat masuknya waktu salat dzuhur (Ali Hasballah, tt.:138).

Contoh-contoh tersebut menggambarkan illat dijadikan sebagai bagian integral dalam kerangka system hukum Islam. Dengan mengetahui illat akan menjadi jelas betapa hukum itu diciptakan Allah untuk mencapai kemaslahatan umat manusia. Maka hukum dapat diketahui diantaranya dengan mengetahui illat.

Pertalian antara illat dan hukum tersebut memunculkan perdebatan di kalangan ulama mutakallimin (ahli kalam), apakah Syari' wajib atau harus menyertakan alasan/illat dalam menetapkan suatu hukum?. Menurut jumhur, Allah tidak wajib mengemukakan illat dalam menetapkan suatu hukum. Mereka berargumen, illat hanya menjadi pertanda atau pengenal adanya hukum (al wasfu al mu'arrifu lilhukmi), atau motiv hukum (al ba'itsu 'alaih) (Syaifuddin al Amidi, 1983:56 dan Al Ghazali, 1983:96). Ini dilandasi oleh doktrin teologis mereka tentang ke-Mahamutlak-an Allah. Sehingga yang berhak menetapkan hukum hanyalah Allah. Allah bisa saja menetapkan hukum tanpa 'illat. Pendapat sebaliknya dikemukakan oleh ulama Mu'tazilah yang memegangi teologi ke-Mahaadil-an Allah. Syari' wajib mengemukakan 'illat pada setiap penetapan hukum. Jika tidak, maka Allah berbuat tidak adil, dan ini tidak mungkin. Sehingga setiap penetapan hukum wajib ada illat atau alasan.

Pemahaman illat yang diungkapkan ulama jumhur berbeda dengan apa yang dipahami oleh Ibn Hazm. Ia mendefinisikan illat sebagai berikut :

Illat adalah nama untuk setiap sifat yang secara pasti mewajibkan sesuatu yang lain. Menurutnya illat tidak pernah berpisah dengan ma'lulnya (sebab dengan akibat). Misalnya api adalah illat bagi terjadinya pembakaran, dingin adalah illat terjadinya es. Hubungan api dengan membakar atau antara dingin dengan es adalah hubungan pasti, tidak dapat dipisahkan dengan terjadinya pada waktu yang sama.

Ibnu Hazm membedakan pula antara 'illat dengan sebab. Yang dimaksud dengan sebab adalah:

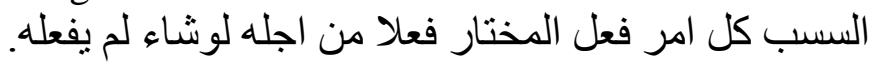


Setiap sesuatu yang didorong oleh kemauannya sendiri untuk berbuat atau tidak berbuat (Ibn Hazm, tt:1128).

Misalnya, marah yang dapat membawa kepada kemenangan. Marah adalah sebab bagi terjadinya kemenangan. Marah kepada penjajah membuat kita melawan penjajah akibatnya terjadi kemenangan. "Sebab" tidak mewajibkan adanya akibat pasti. Misalnya orang yang melawan penjajah sebab marah belum pasti menang. Sebab terjadinya lebih dahulu dari pada akibat. Orang yang marah pada penjajah masih punya pilihan, jika ia mau ia dapat menang tetapi walaupun ia mau tidak mesti menang.

Bila dicermati pengertian 'illat dan sebab yang dikemukakan Ibnu Hazm, nampaknya ada perbedaan dengan apa yang dikemukakan jumhur. Hubungan 'illat dengan ma'mulnya menurut ibn Hazm adalah hubungan yang mewajibkan secara pasti. Sedangkan menurut jumhur hanya pada persangkaan belum sampai kepada tingkat pasti. Maka 'illat menurut jumhur tidak sama pengertiannya dengan 'illat yang dikemukakan Ibn Hazm, tetapi 'illat dalam pengertian jumhur sama dengan sebab dalam pengertian Ibn Hazm.

Dari uraian 'illat yang dimaksud Ibnu Hazm menggambarkan logika yang digunakan Ibnu Hazm. 'illat mesti terjadi pada waktu yang sama dengan madlulnya. Misalnya jika dikatakan khamar itu haram maka keharamannya bukan karena memabukkan, melainkan keharamannya kehendak Allah. Sejak khamr diciptakan Tuhan ia telah memabukkan, maka sejak diciptakannya khamar itu diharamkan. Tetapi pada realita pentasyri'annya khamr pernah dihalalkan pada awal-awal datangnya Islam, sedangkan khmar itu dari dahulu sampai sekarang adalah memabukkan (Ibn Hazm, $\mathrm{tt}: 609)$.

'Illat yang dimaksud Ibnu Hazm bukan datang kemudian. Maka tidak seharusnya mencari 'illat terlebih dahulu baru kemudian menetapkan hukumnya. Karena 'illat seperti ini dapat diartikan adanya campur tangan pihak lain dalam menetapkan hukum selain Allah. Hal ini akan membawa kepada syirik (kufur) dan membuka peluang untuk menentukan hukum kehendaknya (Ibn Hazm, tt:601). Oleh sebab itu 'illat seperti yang dipahami jumhur ulama tidak dapat diterima sebagai landasan hukum.

Adapun argumentasi Ibnu Hazm yang diajukan untuk menolak penalaran 'illat ini didasarkan atas dalil Al Qur'an dan Hadits Nabi saw, antara lain : 
Hadits Nabi yang melarang umat bertanya lebih jauh tentang semua perintah dan larangan Allah:

"Manusia yang paling besar dosanya dalam islam adalah orang yang yang mempertanyakan sesuatu yang tidak diharamkan, lalu diharamkan karena pertanyaan yang diajukan".

Mencari illat sebenarnya sama dengan mempertanyakan alasan sesuatu perintah atau larangan Allah dan Rasulnya. Dengan mempertanyakan (mencari 'illat) akan membawa kepada kesesatan, sebagaimana yang dicantumkan dalam Al-Qur'an:

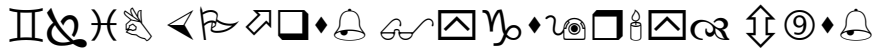
兽\&

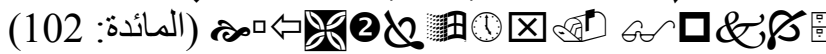

Artinya: "Sesungguhnya telah ada segolongan manusia sebelum kamu menanyakan hal-hal yang serupa itu (kepada Nabi mereka), kemudian mereka tidak percaya kepadanya. (QS. Al Maidah: 102)

$\cos (-) \infty$ है

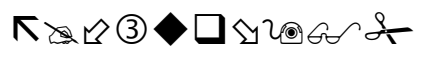

К:

(الانبياء: 18)

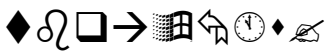

Artinya: "Dan kecelakaanlah bagimu disebabkan kamu mensifati (Allah dengan sifat-sifat yang tidak layak bagi-Nya)". (QS. Al Anbiya': 18)
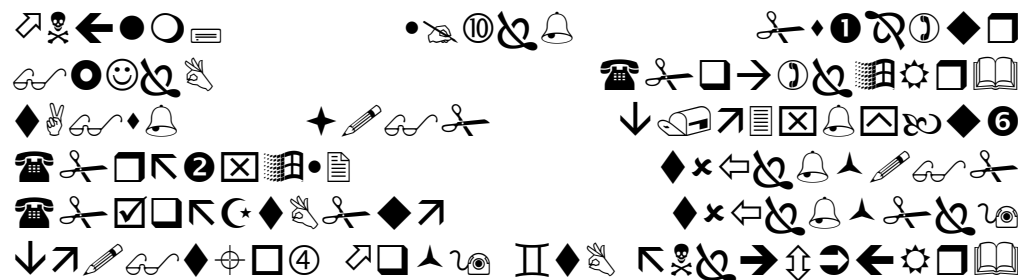

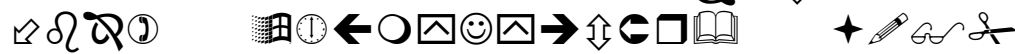

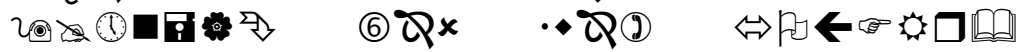
जि

Artinya: "Dan apabila dikatakakan kepada mereka: "Nafkahkanlah sebahagian dari reski yang diberikan Allah kepadamu", Maka orang-orang yang kafir itu berkata kepada orang-orang yang beriman: "Apakah Kami akan memberi Makan kepada orang-orang yang jika Allah menghendaki tentulah Dia akan memberinya 
makan, Tiadalah kamu melainkan dalam kesesatan yang nyata". (QS. Yasin : 47)

Ibn Hazm menginginkan agar setiap Muslim dalam menerima perintah Allah dan mematuhinya tanpa banyak bertanya (mencari 'illat) seperti dalam ayat Allah mengutuk suatu kaum yang bersedekah memberi makan fakir miskin, lalu mereka bertanya kepada Allah untuk apa mereka bersedekah.

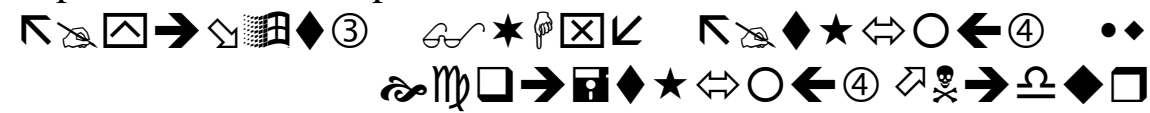

Artinya: "Dia tidak ditanya tentang apa yang diperbuat-Nya dan merekalah yang akan ditanyai". (QS. Al Anbiya' 23)

Ayat ini melarang untuk mempertanyakan perbuatan Tuhan, tetapi perbuatan manusialah yang dipertanyakan.

Ibnu Hazm juga mengatakan, bahwa Nabi Adam telah melakukan kesalahan dua macam: yaitu tidak mematuhi larangan Allah dengan sepenuhnya (tanpa alasan/Illat), dan kedua, Nabi Adam menerima 'illat yang diajarkan iblis, sebagimana diabadikan dalam QS. Al A'raf 19-23.

Dari Hadits dan ayat-ayat yang disebutkan di atas (sebenarnya masih banyak ayat-ayat yang digunakan Ibn Hazm), dapat dipahami Ibnu Hazm ingin menolak penalaran 'illat sebagaimana yang dipahami jumhur ulama, tetapi ia setuju dengan menggunakan istilah sebab terutama sebab yang tertulis dalam nash (al manshushah), dan tidak perlu dicari-cari, tetapi cukup diserahkan kepada Allah.

\section{Penolakan terhadap Qiyas}

Penggunaan qiyas sebagai upaya (ijtihad) dalam menetapkan hukum suatu persoalan yang tidak dijelaskan oleh nash, berawal dari penggunaan ra'yu yang begitu bebas dan liberal terutama pada masa generasi tabi'in (Jurnal Studi Islam, al-Hikmah, Vol. VII/1996: 41). Pada masa berikutnya penggunaan ra'yu secara bebas itu mengalami pembatasan-pembatasan yang bertujuan menghentikan penggunaan semaunya serta mensistematisasikan proses penalaran yang selanjutnya dikenal sebagai qiyas (Ahmad Hasan, Pintu Ijtihad Sebelum Tertutup, Bandung : Pustaka, 1983, hal. 125).

Usaha membatasi penggunaan ra'yu yang pada akhirnya dikenal sebagai qiyas ini, sebenarnya muncul pada periode al- 
Syafi'i dalam teori pemikiran hukumnya. Al-Syafi'i-lah yang secara skematis menempatkan qiyas pada urutan yang keempat sesudah al-Qur'an, As Sunnah, dan Ijma' (Noel J. Coulson, 1987:63-64). Menurut analisis Joseph Schacht, teori hukum alSyafi'i merupakan hasil internalisasi dari pemikiran hukum yang berkembang pada masanya (Joseph Schart, 1965:60). Metode qiyas ini kemudian terus berkembang dan dilanjutkan oleh para pengikutnya. Tetapi dalam perkembangan pemikiran hukum Islam juga muncul ulama yang menolak qiyas dengan berbagai alasan yang mereka kemukakan.

Adapun dalil-dalil mereka, baik yang menerima maupun yang menolak qiyas, akan dikemukakan secara singkat sebagai berikut :

\section{Dalil-dalil Ulama Pendukung Qiyas :}

Para ulama yang mengusung qiyas sebagai dalil dalam menetapkan hukum, untuk melengkapi dalil nash dan ijma', memperkuat pendapatnya dengan berbagai argument, baik dalil naqli maupun aqli, sebagai berikut :

\section{Dalil Al-Qur'an}

Dalil yang biasa dijadikan hujjah dalam penetapan qiyas (dan dalil yang lain) adalah QS. An-Nisa : 59. dalam isi ayat ini kaum muslimin diperintahkan taat kepada Allah (AlQur'an) dan Rasul (As-Sunnah) dan Ulil Amri. Kemudian jika terjadi perselisihan tentang suatu hukum yang tidak secara langsung ada nashnya, maka diperintahkan untuk kembali kepada Allah dan Rasul. Artinya kembali kepada kaidah-kaidah Syari'ah, yang diantaranya adalah Qiyas.

Dalam penutup ayat 2 surat al-Hasyr disebutkan: "Maka ambillah (kejadian itu) sebagai pelajaran, hai orangorang yang mempunyai pandangan". Yang dimaksudkan adalah kiaskan dirimu dengan mereka yang kalau kamu berbuat kerusakan seperti mereka kamu akan menerima balasan sebagaimana yang mereka terima. Kata-kata fa'tabiru dalam ayat tersebut antara lain bisa berupa qiyas.

$\underline{\text { Dalil As-Sunnah }}$ 
Keijinan as-Sunnah untuk pemakaian ar ra'yu atau qiyas sebagai metode menemukan hukum ini ditunjukkan oleh beberapa hadist dan praktek Nabi. Ketika Rasul saw, mengutus Muad bin Jabal ke Yaman Beliau terlebih dahulu bertanya: "Apa yang kau kerjakan sekiranya kau menghadapi perkara?". Muad menjawab, "Aku putuskan berdasarkan Kitab Allah". "Jika tidak kau temukan?". Muad menjawab, "Aku putuskan dengan Sunnah Rasulullah saw". "Jika dalam sunah juga tidak kau temukan?". Kata Nabi lagi. "Aku akan berijtihad dengan pendapatku sendiri" Jawab Muad lagi. Kemudian Rasul menepuk dada Muad seraya memuji Allah (Wahbah al-Zuhaily, Juz I:625). Hadits ini menunjukkan ketetapan Nabi tentang kebolehan ijtihad dengan ra'yu. Dalam riwayat lain, Nabi mengutus Muad dan Abu Musa sebagai qadli di Yaman kemudian ditanya oleh Nabi, dengan apa memutuskan perkara. Mereka berdua menjawab, jika tidak aku temukan sunnah, maka aku qiyaskan suatu perkara dengan perkara yang lain mana yang lebih mendekati kebenaran. Maka Rasul menjawab, "Kau benar" (Wahbah alZuhaily, Juz I:624). Ini menunjukkan wajibnya beramal dengan qiyas.

Contoh lain, ketika seorang laki-laki datang kepada Nabi bertanya tentang ayahnya yang sudah tua tetapi tidak mampu haji, apakah boleh ia menghajikannya?. Kemudian Rasul menjawab:

ارأيت لوكان على أبيك دين فقضيته أكان ينفع ذلك؟ قال نعم، قال : فدين الله أحق بالقضاء

Dalam hadits ini Rasul mengqiyaskan haji dengan hutang kepada manusia (Wahbah al-Zuhaily, Juz I:625).

\section{$\underline{\text { Praktek Sahabat }}$}

Para sahabat banyak menggunakan qiyas sebagai landasan beramal dan tidak ada satupun diantara mereka yang mengingkarinya. Mereka telah sepakat (ijma') bahwa qiyas adalah hujjah yang wajib diamalkan. Contoh-contoh penerapan qiyas atau ungkapan yang mendukung ini banyak sekali diantaranya adalah: 
Abu Bakar ra. pernah memberi penjelasan tentang kalalah (dalam pewarisan), ia berkata (Wahbah al-Zuhaily, Juz I:627).:

$$
\text { أقول فيها بر أي فإن يكن صو ابا فمن الله و إن يكن خطأ فمنّي ومن الثنيطان }
$$

Umar bin Khattab pernah menulis surat kepada Abi Musa alAsy'ari ketika masih menjadi gubernur di Bashrah (Wahbah al-Zuhaily, Juz I:628):

$$
\text { أعرف الأشباه و النّظائر وقس الأمور بر أيك }
$$

(Perhatikanlah segala yang ada miripnya dan persamaannya dan qiyaskan segala perkara dengan pendapatmu). Sahabat Ali juga berkata (Wahbah al-Zuhaily, Juz I:629):

$$
\text { ويعرف الحق بالمقايسة عند ذو الألباب }
$$

(Diketahui yang benar itu dengan melalui qiyas pada orang yang berakal). Ibnu Abbas juga mengqiyaskan nenek dengan cucu yang dapat menghijab bagian saudara yang meninggal (Wahbah al-Zuhaily, Juz I:629).

Beberapa pernyataan dan praktek para pembesar sahabat Nabi ini merupakan suatu pertanda, bahwa qiyas adalah hujjah dan wajib beramal dengannya.

\section{$\underline{\text { Dalil rasional }}$}

Selain alasan-alasan tersebut di atas, penggunaan qiyas juga bisa diterima secara nalar sebagai salah satu metode berfikir yang kuat. Hal ini didasarkan pada kenyataankenyataan sebagai berikut :

1. Setiap hukum Syara' bertujuan untuk memelihara maslahat manusia. Karena itu pada kasus-kasus yang belum disebutkan hukumnya oleh al-Qur'an dan Sunnah namun ada kemiripan dan persamaannya dengan yang disebut dalam al-Qur'an dan Sunnah, maka berarti hukumnya juga sama dengan yang disebutkan. Dengan demikian tujuan yang ingin dicapai hukum syar'i ialah kemaslahatan manusia. Akal yang sehat tidak dapat menerima kalau 'illat diharamkan khamar itu karena memabukkan lalu 'illat yang sama ditemui juga pada nabiz dikatakan tidak haram.

2. Jumlah ayat Al Qur'an dan Sunnah Nabi saw terbatas sedang peristiwa baru yang memerlukan ketentuan hukum 
selalu bermunculan dan kalau sumber hukum hanya terbatas pada nash Al-Qur'an dan As-Sunnah saja, maka jelas banyak kasus baru yang tidak tertampung, karena itu qiyas adalah salah satu sumber tambahan bagi kasus yang belum ada ketentuan hukumnya dalam nash.

3. Qiyas adalah salah satu sumber hukum yang dapat diterima akal yang sehat umpamanya dilarang meminum suatu zat cair yang mengandung racun, maka diqiaskan apa saja zat cair yang mengandung racun dilarang.

4. Penalaran qiyas ini juga dipakai oleh metode modern dalam bentuk induktif dan deduktif. Dan memang pada hakekatnya di dunia ini tidak ada sesuatu yang baru, ada prinsip-prinsip universal yang disepakati. Dan qiyas merupakan manifestasi dari berfikir yang sehat.

\section{Dalil-dalil Ulama Nufatul Qiyas :}

Beberapa ulama yang menggugat dan menolak qiyas sebagai dalil hukum, seperti al-Nazham dan pengikutnya dari kalangan Mu'tazilah, Daud Zhahiri, sebagian kaum Syi'ah dan Ibnu Hazm. Mereka disebut dengan ahl Nufat al-Qiyas, kelompok yang menafikan qiyas. Mereka berargumen, bahwa qiyas bukanlah dalil hukum oleh karena itu tidak bisa dijadikan hujjah Syari'ah dalam menetapkan hukum (Zakaria al-Bir, 1975:113). Bahkan Ibn Hazm dengan tegas menyatakan penolakannya berdasarkan dengan ra'yu dan hanya bersandar kepada al-Qur'an dan Hadits dengan memperhatikan makna dan pengertian lahiriyah (zahirnya) saja. Adapun argumentasi yang dikemukakan Ibn Hazm dalam menolak menggunakan Qiyas antara lain:

a. Dalam Syari'at Islam terdapat bentuk perintah dan larangan, secara garis besar terbagi kepada tiga macam ahkam yaitu: perintah, larangan dan kebolehan. Apabila tidak terdapat nash yang jelas tentang suatu persoalan, maka hal ini akan termasuk kedalam prinsip boleh (ibahah) yang ditetapkan dalam al-Qur'an. Perintah dan Larangan telah ditetapkan dengan otoritas yang jelas dari al-Qur'an, Sunnah dan Ijma'. Apabila tidak ditemukan yang dapat menetapkan perintah atau larangan secara otomatis masuk dalam katagori mubah. Oleh karena itu 
tidak memberi peluang bagi qiyas (analogi) dalam menentukan ahkam (Ibn Hazm: 515).

b. Para pendukung Qiyas (musbit al-Qiyas) mempunyai asumsi bahwa syari'ah tidak menetapkan nash pada setiap permasalahan, maka dalam mengantisipasi ini diperlukan ijtihad, salah satunya dengan penalaran qiyas. Asumsi ini dibantah oleh Ibn Hazm dan menganggap pendapat ini bertentangan dengan ketentuan eksplisit al-Qur'an AlMaidah ayat 3:

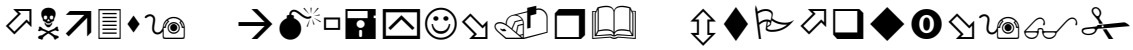

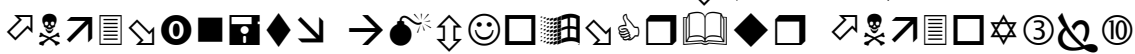

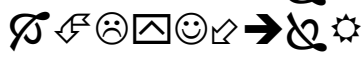

Artinya: "Pada hari ini telah aku sempurnakan agamamu dan aku sempurnakan nikmatku untukmu".

Al-An'am ayat 38:

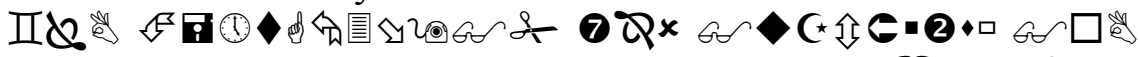

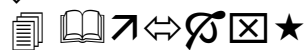

Artinya: "Kami tidak mengalpakan sesuatupun dalam kitab"

Al-Nahl ayat 44:

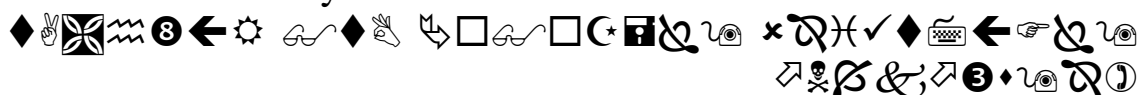

Artinya: "Untuk menjelaskan bagi manusia apa-apa yang telah kami turunkan"

Ahkam adalah berasal dari pemberi hukum, mencakup seluruhnya dan memberi pedoman yang lengkap untuk setiap peristiwa. Ibn Hazm beranggapan bagi orang yang menerapkan qiyas sebagai dalil tambahan sama artinya dengan mengatakan bahwa al-qur'an gagal memberikan pedoman yang lengkap (Ibn Hazm, tt:517).

c. Qiyas sesungguhnya dibangun diatas dasar yang bersifat dzan (persangkaan) dalam menentukan 'illat hukumnya. Dengan sendirinya hukum yang dihasilkannyapun bersifat dzan pula, maka qiyas tidak membawa kepada tingkat keyakinan. Oleh sebab itu menurut Ibnu Hazm qiyas yang bersandarkan perkiraan tidak dapat diterima menjadi dasar ketentuan hukum karena dengan perkiraan tidak membawa kepada kebenaran, dalil al-qur'an (Ibn Hazm, tt: 555): 


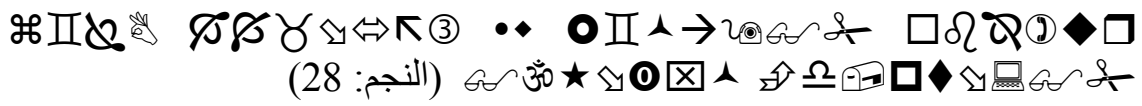

d. Ibnu Hazm berpendapat bahwa qiyas secara jelas dilarang dalam al-qur'an(Ibn Hazm, tt:521-522). Sebagaimana yang terdapat pada QS. al-Hujarat : 1, al-An'am : 38, Maryam : 64.

Sebagai kesimpulan argumentasinya ini, Ibnu Hazm menegaskan dua hal : Pertama, bahwa nash Al-Qur'an dan hadits Nabi mampu menjawab seluruh peristiwa. Kedua, bahwa qiyas adalah merupakan tambahan, tidak perlu bagi nash (Hasyim Kamali: 285).

\section{B. Cara Ibn Hazm Memahami dan Menggunakan Dalil}

Dalil-dalil syari'at dalam menetapkan hukum sebagaimana yang disepakati oleh jumhur Ulama berpangkal kepada 4 (empat) macam yaitu: al-Qur'an, al-Sunnah, al-Ijma'dan al-qiyas (Abdul Wahab al-Khalaf: 21). Adapun dalil mengenai penggunaan empat dalil itu disebutkan dalam firman Allah QS An Nisa' 59. Dalam ayat Tersebut ditegaskan, bahwa perintah mentaati Allah dan Rasulnya artinya mengikuti al-Qur'an dan Sunnah Nabi. Sedang mentaati ulil Amri artinya mengikuti hukum-hukum yang telah disepakati oleh Mujtahidin (ijma') dan perintah mengembalikan kepada Allah dan Rasulnya artinya mengikuti qiyas (Abdul Wahab al-Khalaf: 21).

Ibnu Hazm yang menolak 'illat dan qiyas, dalam memahami ayat di atas, ia jadikan juga sebagai dasar urutan dalil-dalil Syari'at menurut metodenya. Perintah pertama mentaati Allah maksudnya mematuhi al-Qur'an menjadi rujukan pertama. Perintah kedua mentaati Rasul maksudnya mengikuti Hadits Nabi. Perintah ketiga mentaati para pemimpin maksudnya mengikuti ijma'. Dan selanjutnya apabila terjadi perbedaan dikembalikan kepada Allah dan Rasulnya, maksudnya dikembalikan kepada nash al-Qur'an dan nash Hadits Rasul yang sahih (Ibn Hazm, Juz I: 95-96).

Dalam menyelesaikan berbagai masalah fiqih, Ibnu Hazm mempunyai cara tersendiri, yang dijadikannya urutan sebagai penalarannya sebagaimana yang ia sebutkan:

Rujukan yang diperlukan untuk mengetahui hukum Syari'at ada empat: Nash al-qur'an, nas Hadits yang shahih yang diriwayatkan oleh para perawi yang dapat dipercaya atau 
dinukilkan secara mutawatir, ijma' atau dalil yang hanya mengandung satu pengertian (Ibn Hazm, Juz I: 70).

Dari kutipan di atas dapat dipahami bahwa cara Ibnu Hazm untuk menetapkan suatu hukum melalui 4 (empat) macam, yaitu alQur'an, Hadis Nabi yang shahih, Ijma' dan Dalil.

\section{a. Al-Qur'an}

Nash dalam Al-Qur'an menurut Ibnu Hazm semuanya sudah jelas dan mencakup semua yang telah disyari'atkan Allah, kecuali pada huruf-huruf fawatihushshuwar dan kalimat-kalimat Qasam pada awal surat (Ibn Hazm, Juz IV: 534). Selain kedua macam ini, seluruh nas al-Qur'an sudah jelas dan lengkap. Untuk menguatkan pendapatnya Ibnu Hazm mendasarkan pada ayat:

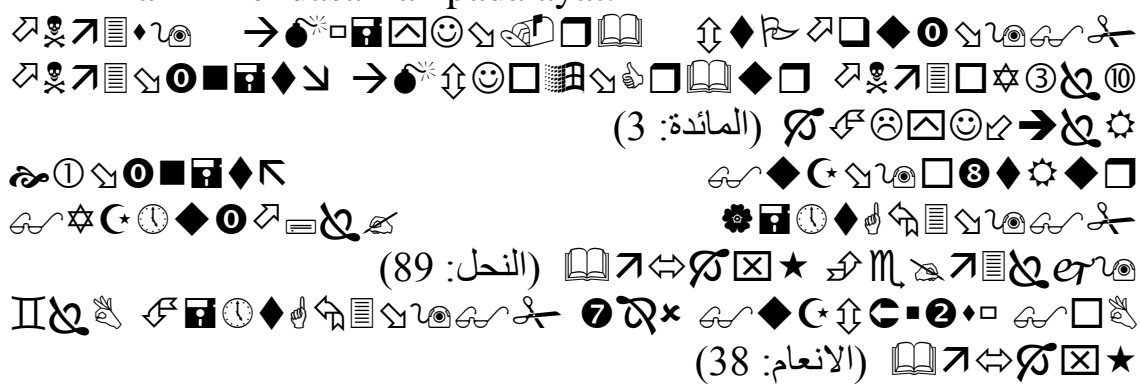

Kejelasan nash al-Qur'an tidak selamanya jelas dengan nash itu sendiri. Apabila nas al-Qur'an tidak jelas dengan sendirinya maka diperlukan penjelasan nash lain dari ayat alQur'an, dapat pula dijelaskan melalui hadis atau ijma'. Penjelasan nash al-qur'an dengan nash al-qur'an lainnya dapat dilakukan dengan cara tafsir, takhsis, istisna, dan ta'kid. Penerapannya dalam penalaran hukum Islam dapat dicontohkan sebagai berikut :

1. Tafsir: Masalah talaq yang terdapat pada beberapa surat seperti pada surat al-Baqarah, ditafsirkan secara rinci dalam surat al-Talaq. Contoh lain dalam al-Qur'an Allah berfirman (wa atuu al-zakat), maka melalui hadis-hadis rasul menafsirkan apa-apa yang harus dikeluarkan zakatnya, demikian pula dalam menafsirkan sifat-sifat nikah, haji dan lain-lain (Ibn Hazm, Juz I: 79). 
2. Takhshish: Pada surat al-Baqarah ayat 221 menyebutkan tentang larangan orang Islam kawin dengan wanita-wanita musyrik secara keseluruhannya. Kemudian surat alMaidah ayat 5 menjelaskan tentang kebolehan kawin dengan wanita ahli kitab. Ini artinya bahwa surat alMaidah ayat 5 tersebut mentakhsis surat al-Baqarah ayat 221.

3. Istisna': Kelihatan Ibnu Hazm membedakan istisna' dengan takhsis. Apabila kata pengecualian itu pada kalimat yang sama (muttasil) maka ini disebutkan sebagai istisna'. Seperti pada surat al-Mukminun ayat 6 menjelaskan, memelihara kehormatan (al-Furuj) kecuali terhadap istri-istri dan budak-budak mereka. Pengecualian pada ayat ini dimasukkan pada istisna'. Apabila pengecualian itu pada kalimat yang lain (munfasil) maka ini yang dikatakan takhsis. Sedangkan jumhur Ulama memandang takhsis adalah mengeluarkan sebagian dari lafaz umum, bukan seluruh satuannya, baik pada satu kalimat (muttasil) atau pada kalimat yang lain (munfasil).

4. Ta'kid: Dalam surat al-Baqarah ayat 196 dinyatakan:

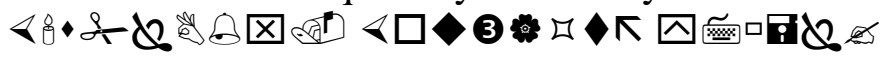

Kalimat ini dianggap sebagai ta'kid bagi kalimat sebelumnya:

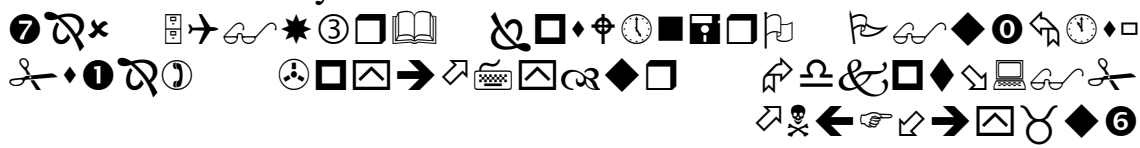

Dari metode ini Ibn Hazm secara langsung dapat menyelesaikan ketidakjelasan ayat-ayat yang ada dengan melalui penafsiran, pentakhsihan, istisna dan ta'kid. Berdasarkan hal ini, ia berpendirian bahwa ayat-ayat alQur'an semuanya telah jelas dan tanpa memerlukan penalaran logika diluar nash.

Di samping itu menurut Ibnu Hazm perintah dan larangan dalam al-Qur'an dan hadis, wajib untuk dilakukan kecuali ada dalil yang mengalihkan kepada sunnah atau mubah apabila nash itu berbentuk perintah (amr). Sedangkan larangan (nahi) menunjukkan haram kecuali ada dalil lain 
yang mengalihkannya menjadi makruh (Ibn Hazm, Juz III: 275).

b. Al-Sunnah (Al Hadits)

Kedudukan hadis sebagai rujukan hukum tidak jauh berbeda dengan al-Qur'an, karena hadis juga merupakan wahyu. Rasul tidak akan berbicara sekehendaknya menurut seleranya, tetapi semuanya berdasarkan wahyu (an-Najm 34).

Keterkaitan antara hadis dengan al-Qur'an, kelihatannya Ibnu Hazm tidak jauh berbeda dengan teori yang dipakai Imam Syafi'i yang memandang al-Qur'an dan Hadis sebagai suatu kesatuan yang tidak dapat dipisahkan. Keduanya saling melengkapi dan menjelaskan, keduanya disebut nash yang berasal dari wahyu. Nas Nadits itu ada yang sudah jelas dengan sendirinya, ada yang perlu dijelaskan oleh nash al-Qur'an, nash Hadits yang lain atau dengan ijma', oleh karena itu tidak mungkin terjadi pertentangan antara hadis dengan al-Qur' an, karena keduanya bersumber dari Allah, dengan alasannya ayat al-qur'an:

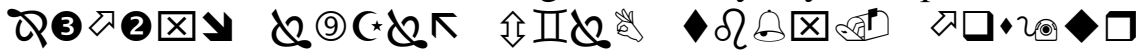

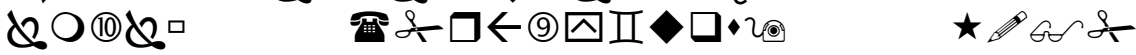

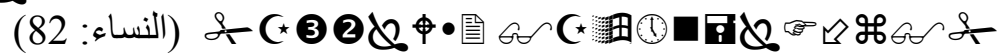

Ibnu Hazm membagi hakekat sunnah kepada tiga macam, sebagaimana ulama lainnya yaitu, sunnah qauliyah, sunah fi'liyah dan sunah taqririyah. Menurutnya sunah qauliyah saja yang dapat menunjukkan wajib, sedangkan sunah fi'liyah hanya sebagi contoh (uswah) dan sunnah taqririyah memfaedahkan kepada kebolehan (ibahah) (Ibn Hazm, Juz II: 149). Tetapi walaupun demikian perbuatan Nabi yang berhubungan dengan tugas kenabian dan penjelasan Syari'at, seperti cara shalat, haji, tayammum dan sebagainya, ini juga wajib diikuti karena perbuatan itu merupakan petunjuk dan perintah yang merupakan wahyu yang ada dalam al-Qur'an.

Dari segi kuantitas hadis, Ibnu Hazm membagi hadis kepada dua, mutawatir dan ahad (Ibn Hazm, Juz IV: 102, 106). Hadis mutawatir menurutnya memberikan informasi 
yang pasti meyakinkan dan dapat dijadikan dalil. Sedangkan Hadits ahad memberikan informasi yang dapat diterima, walaupun tidak sekuat hadis mutawatir dan keduanya wajib diamalkan.

Dari penjelasan di atas terlihat corak penalaran Ibn Hazm menjadikan al-Qur'an dan sunnah tidak terpisahkan dan saling berkaitan. Jika hadis telah jelas dengan sendirinya, maka hadis dapat dipakai secara langsung, jika tidak jelas dilihat kepada nash al-qur'an. Dengan pemahaman hadis seperti ini benar-benar Ibnu Hazm dalam pemakaian dalil dari nash yang murni tanpa memerlukan penalaran diluar nas.

c. Ijma'

Ijma' yang dimaksud ibnu Hazm yaitu apabila siapa saja yang mengikuti nash al-Qur'an dan Hadits Nabi yang sahih berarti ia telah mengikuti ijma' dengan pasti. Baginya tidak ada ijma' kecuali berdasarkan nash. Ayat yang digunakannya sebagai alasan ada;ah :

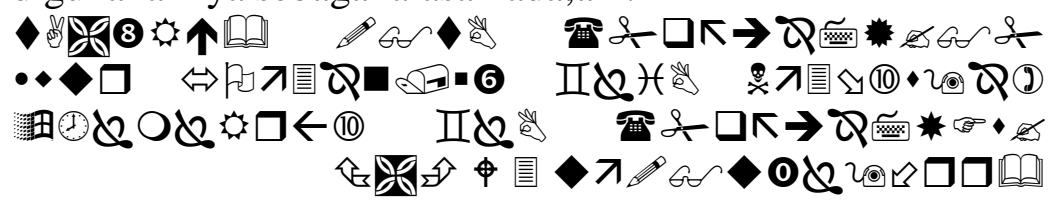

Artinya: "Ikutilah apa yang diturunkan kepadamu dari Tuhanmu dan janganlah kamu mengikuti pemimpin-pemimpin selain-Nya.

Pengertian dari surat al-A'raf ayat 3 ini, Allah memerintahkan untuk mengikuti semua yang telah diturunkannya (wahyu/nash) (Ibn Hazm, Juz IV: 545). Pendapat seseorang yang tidak sesuai dengan nash maka ini dianggap pendapat yang batal. Ijma' yang masih mempergunakan qiyas dan 'illat kemudian meluas kesepakatan selain sahabat, ijma' seperti ini adalah batal (bertolak).

Maka menurut Ibnu Hazm bentuk ijma' ada dua: Pertama, semua masalah yang tidak diragukan lagi oleh setiap muslim, misalnya wajibnya membaca sahadat, kewajiban shalat lima waktu, puasa ramadhan, haramnya bangkai, darah, khamar, wajibnya membayar zakat dan sebagainya. Maka hal ini merupakan ijma' seluruh umat 
Islam, karena hal ini berlandaskan nash. Inilah yang dinamakan ijma', orang yang tidak mengakui semua itu bukan seorang muslim. Kedua, perbuatan Nabi yang disaksikan oleh seluruh sahabat atau diyakini oleh sahabat yang lain walaupun mereka tidak hadir pada dalam peristiwa itu. Misalnya perbuatan Nabi memberikan kepada orang Yahudi setengah hasil pertanian Khaibar, padahal kalau umat Islam mau dapat mengusir orang Yahudi dari Khaebar (Ibn Hazm, Juz IV: 555).

Jika dicermati pendapat Ibnu Hazm tentang bentuk ijma' pertama, sebenarnya hal itu telah diajukan imam Syafi'i yang disebutnya dengan ijma' al- 'ammah. Sedangkan bentuk ijma' kedua adalah ijma' yang diakui ibnu Hazm adalah sebatas ijma' sahabat, karena jumlah sahabat terbatas, kualitas keimanan mereka tidak diragukan dan pemahaman mereka juga bukan jauh dari nash.

d. Dalil

Dalil yang dimaksud Ibnu Hazm adalah (Ibn Hazm, Juz I: 40): عبارة يتبين بها المر اد "ungkapan yang dapat menerangkan apa yang dimaksudkan". Ibnu Hazm dalam menentukan hukum suatu masalah lebih dahulu merujuk kepada nash alQur'an, nash Hadis dan Ijma'. Bila ternyata tidak terdapat jawabannya pada ketiga rujukan itu maka ia menggunakan dalil. Dalil diperoleh dari nash secara implisit, bukan secara eksplisit (jelas) dalam nash, ia merupakan pemahaman yang ditangkap dari nash.

Pemahaman yang dilakukan terhadap nash inilah yang dinamakan dalil, dimana untuk sampai pada pemahaman itu dapat diperoleh melalui logika kebahasaan atau dapat dikatakan dalil itu diperoleh dari pemahaman kebahasaan. Walaupun demikian dalil yang dimaksud Ibnu Hazm itu tidak terlepas dari nash Al-Qur'an, nash Hadis dan ijma'. Maka menurutnya, dalil itu ada yang berasal dari nash dan ada yang berasal dari ijma' (Ibn Hazm, Juz V: 100).

Sebagai contoh pemakaian dalil dalam penalaran Ibnu Hazm, antara lain dalam surat an-Nisa' 11: 


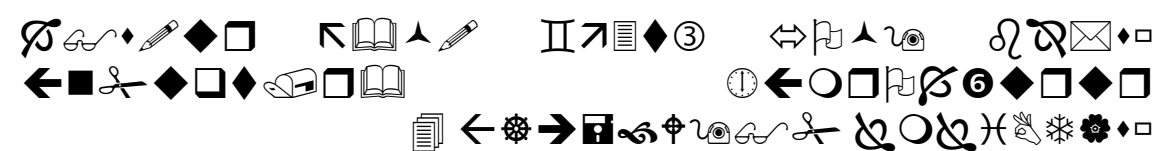

Artinya: "jika orang yang meninggal tidak mempunyai anak dan ia diwarisi oleh ibu-bapanya (saja), maka ibunya mendapat sepertiga".

Nas ini menyebutkan secara jelas melalui zahir nas, bahwa bila seseorang wafat ia tidak mempunyai anak, ahli waris hanya seorang ibu dan bapak saja. Dalam ayat itu ibu mendapat sepertiga bagian sedangkan bagian bapak tidak disebutkan dalam nas, maka dari nas ini dapat dipahami bila ibu mendapat sepertiga maka tentu bapak sebagai ahli waris ashabah mendapatkan sisanya, yaitu dua pertiga karena ahli warisnya hanya ibu dan bapak saja (Ibn Hazm, Juz I: 68). Maka pemahaman mendapatnya ayah dua pertiga tersebut inilah yang dinamakan dalil.

Contoh yang lain disebutkan dalam surat at-Taubah 114:

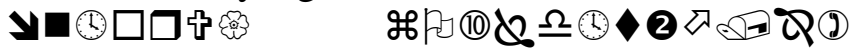

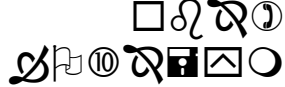

Ayat ini dinyatakan, Ibrahim itu seorang yang sangat lembut hatinya dan sangat penyantun. Maka dari ayat ini dapat dipahami (dalil) bahwa Ibrahim itu bukan orang yang idiot, ia penyayang, berhati bersih, ikhlas dan sebagainya. Ini berarti dari satu lafadz dapat dipahami beberapa pengertian lain yang hakekatnya sama (Ibn Hazm, Juz V: 101). Dalam ilmu logika pemahaman ini disebut dengan al-Mutalaim. Ibnu Hazm mengatakan, pemakaian logika seperti ini sangat diperlukan karena terkadang ada proposisi-proposisi yang nampaknya berbeda tetapi sebenarnya maknanya sama.

Penalaran Dalil yang digunakan Ibnu Hazm ini, ada bermacam-macam metode, secara garis besar ia membaginya kepada 7 macam:

1. Dalam menetapkan konklusi (natijah) yang tidak ada pada nas, kedua premisnya harus bersumber pada nas seperti:

$$
\text { كل مسكر خمر وكل خمر حرام نتيجة كل مسكر حرام }
$$

2. Memberlakukan secara umum bagi nash-nash yang mempunyai syarat (bergantung pada syarat tertentu) misalnya:

$$
\text { اذا ينتهو ا يغفر لهم ما قد سلف }
$$


Dalil yang dapat diambil dari ayat ini menurutnya, siapa saja yang berhenti berbuat dosa akan diampuni Allah kesalahannya. Sebenarnya ayat ini ditujukan kepada orang-orang kafir tetapi Ibnu Hazm tidak membedakannya termasuk orang yang beriman.

3. Memahami lafadz melalui mutakalimat/ al-Mutarodif/ ان ابراهيم لاواه synonim, seperti pemahaman ayat diatas tadi حليم

4. Bila nash memerintahkan sesuatu maka hukumnya wajib, bila nash melarang sesuatu maka hukumnya haram untuk dilakukan dan jika nas tidak ada untuk melarang atau memerintahkan maka sesuatu itu mubah untuk dilakukan.

5. Qadiyah yang lebih tinggi tetapi tidak mempunyai nash dapat dihubungkan dengan qadiyah sesudahnya yang mempunyai nash. Misalnya :

\section{Abu Bakar lebih mulia dari Umar}

Umar lebih mulia dari Usman, maka tidak diragukan lagi Abu Bakar lebih mulia dari Usman.

6. Membalikkan konklusi termasuk dalam dalil, seperti konklusi "Setiap yang memabukkan haram" dibalikkan menjadi "Sebagian yang diharamkan adalah khamar".

7. Kalimat yang mengandung banyak pengertian misalnya kalimat, zaid menulis (زيد يكتب) kalimat ini mengandung pengertian si Zaid hidup, pandai menulis, mempunyai anggota tubuh dan sebagainya (Ibn Hazm, Juz V: 101102).

Penggunaan nash al-Qur'an, nash Hadis, ijma' dan dalil dalam pemakaiannya inilah yang dinyatakan Ibnu Hazm sebagai al-Burhan. Untuk memahami pengertian al-Burhan yang dimaksud Ibnu Hazm akan dijelaskan di bawah ini.

\section{E. Pengertian dan Persyaratan Al-Burhan}

Secara umum al-Burhan pengertiannya adalah alasan, argumentasi atau hujjah. Pemakaian kata-kata al-Burhan adalah istilah yang sering digunakan Ibnu Hazm dalam berdebat dengan lawan pendapatnya. Sebagaimana yang sering di temukan dalam kitab "al-Muhalla", setelah ia menerangkan pendapatnya lalu 
didukung dengan al-Burhan. Pemakaian istilah al-Burhan ini didasarkan pada ungkapan al-Qur'an:

$$
\text { قل هاتو ا بر هانكم ان كنتم صادقين }
$$

Artinya: "Mana bukti demonstratif (burhan) dari pendapat kaum jika kamu orang yang benar".

Penalaran al-Burhan adalah mencakup semua penalaran yang dipakai Ibnu Hazm baik melalui nash al-Qur'an, nash Hadis, ijma' dan dalil. Tetapi yang populer pemakaian al-Burhan adalah penalaran dalam menetapkan hukum yang tidak dapat dilakukan melalui nash atau ijma', lalu memerlukan penalaran melalui dalil. Metode-metode penalaran dalil ini yang disebut dengan al-Burhan.

Definisi al-Burhan adalah (Ibn Hazm, Juz I: 140):

$$
\text { البر هان: كل قضية او قضايا دلت على حقيقة حكم الثيئ }
$$

Artinya: "Burhan adalah setiap premis atau beberapa premis yang menunjukkan hakikat suatu hukum".

Al-Burhan adalah suatu prosedur penalaran yang sistematik untuk menghasilkan suatu kesimpulan yang benar atas dasar-dasar premis-premis yang benar (Mukhtar Bahar, 1996: 89-90). Untuk sampai kepada natijah yang benar, ada beberapa ketentuan sebagai berikut :

1. Diperlukan dua proposisi (al-Qadaya/ rangkaian pengertian/Premis) dimana setiap proposisi terdiri dari subyek dan predikat (maudhu' dan mahmul).

2. Dalam kedua proposisi diperlukan satu kata (term/lafadz) yang berulang disebutkan pada proposisi pertama dan kedua. Kata yang disebutkan berulang ini dinamakan term tengah (termius medius/al-hadd al-musytarak), kata inilah yang menyamakan antara kedua proposisi itu, dengan bantuan term tengah ini konklusi penalaran dapat ditemukan, tetapi term tengah ini tidak terdapat dalam konklusi.

3. Harus ada kata khusus yang disebut pada proposisi yang pertama dan kedua, kata khusus ini bersumber dari nas, contoh:

$$
\text { حديث: كل مسكر خمر وكل خمر حرام (رواه ابو داود والترميذى }
$$

4. Adanya konklusi (natijah) yang bukan berasal dari nas:

Natijahnya (Ibn Hazm, tt.:108):

$$
\text { كل مسكر خمر وكل خمر حر ام }
$$

Yudisia, Vol. 9, No. 1, Jan-Jun 2018 


$$
\text { كل مسكر حرام }
$$

Disini kesimpulan yang diambil Ibnu Hazm sama dengan kesimpulan yang diambil jumhur ulama, hanya penalaran yang digunakan berbeda. Jumhur menetapkan dengan ('illat diharamkannya khamar adalah karena memabukkan, 'illat ini diperluas kepada semua minuman yang memabukkan. Sedangkan Ibnu Hazm tidak melalui 'illat tetapi ia memakai dalil yaitu menetapkan nash sebagai premis mayor dan premis minor, lalu menarik kesimpulan (konklusi) berdasarkan kedua premis itu.

Penalaran yang menggunakan premis mayor, premis minor dan konklusi dalam bahasa Yunani disebut dengan "sillogisme", dan dalam bahasa Arab sering diartikan dengan al-Qiyas. Tetapi Ibnu Hazm lebih suka menggunakan istilah al-Burhan, karena ia yakin bahwa al-Burhan inilah yang menjadi tujuan utama dalam kajian ilmu logika. Dengan menguasai al-Burhan, Ibnu Hazm berani menantang dan berdebat dengan lawan pendapatnya. Hal ini terbukti Ibnu Hazm adalah salah seorang ulama Fiqih yang sulit dibantah pendapatnya, dikarenakan logika yang kuat dimiliki Ibnu Hazm.

\section{F. Kesimpulan/Penutup}

Ibn Hazm diakui sebagai seorang ulama yang memiliki kontribusi luar biasa dalam dunia Islam. Tak kurang dari 400 judul kitab telah ditulisnya. Melalui karya-karyanya itu, ia diakui sebagai filusuf, teolog, sejarawan, sastrawan, pakar fikih, negarawan, akademisi dan politisi yang handal. Dua karya monumentalnya al Ihkam fi Ushul al Ahkam (Ushul Fikih) dan kitab al Muhalla (Fikih) menjadi rujukan utama fuqaha mu'ashirin (pakar fikih kontemporer) dalam upaya penyelarasan khazanah fikih Islam.

Di kalangan sarjana Islam, Ibnu Hazm dikenal sebagai ilmuwan yang memiliki keunikan dalam kajian-kajiannya. Ia memiliki metodologi sendiri dalam memahami ajaran Islam yang berbeda dengan fuqaha arba'a (ulama empat madzhab). Diantaranya dapat dikemukakan sebagai berikut :

1) Ia menolak al qiyas (dalil analog) yang telah disepakati oleh jumhur ulama (mayoritas ulama) sebagai salah satu landasan hukum syari'at. Karena menurutnya persoalan agama tidak boleh dipecahkan dengan al Qiyas dan ar Ra'yu. Jika ada perselisihan pendapat dalam Islam harus dikembalikan pada 
al Qur'an dan as Sunnah. Nash menurutnya dapat menjawab semua persoalan, karena Din yang diturunkan Allah telah lengkap. Maka ia menolak penalaran melalui 'illat dan qiyas.

2) Menurutnya sumber ajaran Islam ada empat, yaitu nash $\mathrm{Al}$ Qur'an, As Sunnah, Ijma', dan Dalil. Masalah-masalah yang tidak ditemukan hukumnya dalam nash dan ijma', maka harus dikembalikan kepada ketiganya dengan cara memperluas makna kata. Hukum taklifi menurutnya hanya ada tiga, yaitu wajib, haram, dan mubah. Jika suatu perkara tidak ditemukan nash atau ijma yang mewajibkan atau mengharamkan, maka hukumyang adalah mubah.

3) Metodologi yang dipakai yaitu menggunakan jalur tekstual dalam memahami syari'at Islam, dengan menolak analogi (qiyas) sebagaimana yang dipakai oleh empat mazhab. Metodologi pemikiran tekstual Ibnu Hazm itu mengambil kandungan kata dan bukan intisari makna sebuah dalil atau ayat. Metode ini bersandar pada dua inti dasar. Pertama, berpegang pada teks-teks Al Quran, Hadits dan Ijma'. Kedua, tidak menerima dalil qiyas, istihsan, sebagaimana yang dipakai oleh empat mazhab. Ibnu Hazm juga gencar mengkampenyakan agar kaum muslimin tidak taqlid kepada para pemimpin madzhab. 


\section{DAFTAR PUSTAKA}

Ibnu Hazm al-Dzahiri, Al-Ihkam fi Ushul al Ahkam, Bairut Libanon : Dar Al Kutub al Ilmiyah, tt.

Al-Muhalla, Beirut : Maktabah at-Tijadi, tt.

M. Mustafa Syalaby, Ta'lil al-Ahkam, Bairut : Dar al-Nahdhah alArabiyah, 1981

Abdul Wahab al-Khalaf, Ilmu Ushul Fiqh, Kuwait : Dar al-Qalam, 1978. al Qalam, 1972/1392.

Ali Hasballah, Ushul Tasyri' al-Islam, Mesir : Dar al-Ma'arif, tt.

Syiafuddin al Amidi, Al Ihkam fi Ushulil Ahkam, Bairut : Dar al Kutub Al Ilmiyyah, 1983

Al Ghazali, Al Mustashfa fi ilmil Ushul, Bairut : Dar al Kutub Al Ilmiyyah, 1983.

Jurnal Studi Islam, al-Hikmah, Vol. VII/1996, Jakarta : Penerbit Mizan.

Ahmad Hasan, Pintu Ijtihad Sebelum Tertutup, Bandung : Pustaka, 1983.

Noel J. Coulson, Hukum Islam dalam Persfektif Sejarah, Jakarta : PT. Firdaus Surya Grafindo, 1987.

Joseph Schart, An Introduction to Islamic Law, London : Oxfo University, 1965.

Wahbahal-Zuhaily, Ushul al-Fiqh al Islamy, Juz I, Bairut Libanon : Dar al-Fikr.

As Shan'ani, Subulussalam, juz.

Zakaria al-Bir, Masadir al-Ahkam al-Islamiyah, Dar al-Ittihadiyah al-Araby, 1975

Mukhtar Bahar, Pemikiran Ibn Hazm tentang 'Illat antara Konsep dan Aplikasinya, (Tesis), Banda Aceh : PPS IAIN Ar-Raniry, 1996. 